\title{
A global database of soil respiration data
}

\author{
B. Bond-Lamberty and A. Thomson \\ JGCRI/Pacific Northwest National Laboratory, College Park, Maryland, USA
}

Received: 9 February 2010 - Published in Biogeosciences Discuss.: 19 February 2010

Revised: 28 May 2010 - Accepted: 1 June 2010 - Published: 15 June 2010

\begin{abstract}
Soil respiration $-R_{\mathrm{S}}$, the flux of $\mathrm{CO}_{2}$ from the soil to the atmosphere - is probably the least well constrained component of the terrestrial carbon cycle. Here we introduce the SRDB database, a near-universal compendium of published $R_{\mathrm{S}}$ data, and make it available to the scientific community both as a traditional static archive and as a dynamic community database that may be updated over time by interested users. The database encompasses all published studies that report one of the following data measured in the field (not laboratory): annual $R_{\mathrm{S}}$, mean seasonal $R_{\mathrm{S}}$, a seasonal or annual partitioning of $R_{\mathrm{S}}$ into its sources fluxes, $R_{\mathrm{S}}$ temperature response $\left(\mathrm{Q}_{10}\right)$, or $R_{\mathrm{S}}$ at $10^{\circ} \mathrm{C}$. Its orientation is thus to seasonal and annual fluxes, not shorter-term or chamberspecific measurements. To date, data from 818 studies have been entered into the database, constituting 3379 records. The data span the measurement years 1961-2007 and are dominated by temperate, well-drained forests. We briefly examine some aspects of the SRDB data - its climate space coverage, mean annual $R_{\mathrm{S}}$ fluxes and their correlation with other carbon fluxes, $R_{\mathrm{S}}$ variability, temperature sensitivities, and the partitioning of $R_{\mathrm{S}}$ source flux - and suggest some potential lines of research that could be explored using these data. The SRDB database is available online in a permanent archive as well as via a project-hosting repository; the latter source leverages open-source software technologies to encourage wider participation in the database's future development. Ultimately, we hope that the updating of, and corrections to, the SRDB will become a shared project, managed by the users of these data in the scientific community.
\end{abstract}

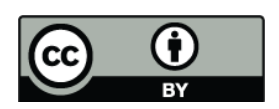

Correspondence to: B. Bond-Lamberty (bondlamberty@pnl.gov)

\section{Introduction}

Soil respiration $-R_{\mathrm{S}}$, the flux of carbon dioxide from the soil surface to the atmosphere - comprises the second-largest terrestrial carbon (C) flux (IPCC, 2001; Raich and Potter, 1995); at $75-100 \mathrm{PgC}^{-1}$, it is an order of magnitude larger than anthropogenic fossil fuel combustion (Boden et al., 2009), implying that $\sim 10 \%$ of atmospheric $\mathrm{CO}_{2}$ cycles through the soil annually (Reichstein and Beer, 2008). This large flux comes from a large pool: globally, soils store at least twice as much $\mathrm{C}$ as is in the atmosphere (Tarnocai et al., 2009; Post et al., 1982). Given that climate models predict mid- and high-latitude warming throughout this century (IPCC, 2007), a critical question is whether enhanced $R_{\mathrm{S}}$ will constitute a significant climate feedback (Jenkinson, 1991; Knorr et al., 2005; Davidson and Janssens, 2006). Such a feedback would have significant consequences for the global C cycle and rates of climate change (Jones et al., 2003; Rustad et al., 2000) and affect policy decisions based on the valuation of terrestrial C fluxes (Wise et al., 2009).

Because of its high variability, inaccessibility of the soil medium, and high cost of measurement instruments (Savage et al., 2008), $R_{\mathrm{S}}$ remains the least well constrained component of the terrestrial C cycle (Trumbore, 2006; Davidson et al., 2006). The spatial variability of $R_{\mathrm{S}}$, and our inability to measure it remotely, remain significant constraints to regional and global evaluations of its magnitude and climate feedback potential; modeling efforts linking observations at different scales are critical to future progress in this arena (Reichstein and Beer, 2008). As the integrated result of a broad spectrum of autotrophic and heterotrophic respiratory processes operating under wildly varying environmental constraints, the temporal and spatial dynamics of $R_{\mathrm{S}}$ remain difficult to model or predict (Zobitz et al., 2008).

A better understanding of $R_{\mathrm{S}}$ flux dynamics will come from elucidating the integrated effects of environmental constraints on soil biotic and abiotic processes, based on the

Published by Copernicus Publications on behalf of the European Geosciences Union. 
kinetic properties of soil organic compounds (Davidson and Janssens, 2006). It is also important, however, to leverage the thousands of $R_{\mathrm{S}}$ observations made over decades (Singh and Gupta, 1977; Raich and Schlesinger, 1992; Schlesinger, 1977; Chen and Tian, 2005; Hibbard et al., 2005). This is particularly important for understanding $R_{\mathrm{S}}$, as it has been almost 20 years since the last comprehensive $R_{\mathrm{S}}$ data collection and meta-analysis was published (Raich and Schlesinger, 1992); $80 \%$ of $R_{\mathrm{S}}$ studies have appeared since that time (Fig. 1), a number large enough to deter or limit most data collection projects. Nonetheless, a global, community $R_{\mathrm{S}}$ data set would be useful both on its own and in conjunction with remote sensing, eddy covariance, soils and other databases that either exist or are being assembled, opening the possibility of identifying large-scale patterns not visible in individual studies. Such meta-analyses can result in unexpected or interesting results, even if they are sometimes subject to particular statistical issues, e.g., the "file drawer" problem (Rosenthal, 1979). For example, a database recently assembled to support a meta-analysis of $\mathrm{C}$ balance in relation to stand age (Luyssaert et al., 2007) led to a provocative hypothesis about the controls on forest $\mathrm{C}$ sequestration (Luyssaert et al., 2008). Other reviews and meta-analyses have drawn similarly broad, if tentative, inferences on ecosystem structure and function (Elser et al., 2007; LeBauer and Treseder, 2008; Lusk and Warton, 2007; Rustad et al., 2001; Wan et al., 2001; Hanson et al., 2000).

Meta-analyses are thus not new, but recent efforts to assemble large shared data sets in the earth system sciences make use of Internet-facing databases and modern computational tools, allowing for a vastly expanded pool of potential users, increased analytical power, and increased public trust (Anonymous, 2009). New data-sharing models can also be applied; in particular, technologies such as version control, developed and exploited by the open-source software movement (Raymond, 2001), enable a "living" database that is continually expanded and improved by its users. These new technologies drive the goals of this study: to assemble a nearuniversal database of all published $R_{\mathrm{S}}$ data and make it available to the scientific community, both as a traditional static archive and as a dynamic community database.

\section{Methods}

\subsection{Data sources and inclusion criteria}

We collected all available studies in the peer-reviewed scientific literature reporting $R_{\mathrm{S}}$ measured in the field; lab incubation studies were not included. The ISI Web of Science ${ }^{\mathrm{TM}}$ constituted the primary source of published studies; search terms used included "soil respiration," "soil $\mathrm{CO}_{2}$ evolution," etc. Each study's title and abstract was used to decide whether to acquire it; $\sim 40 \%$ of the almost 4700 studies were

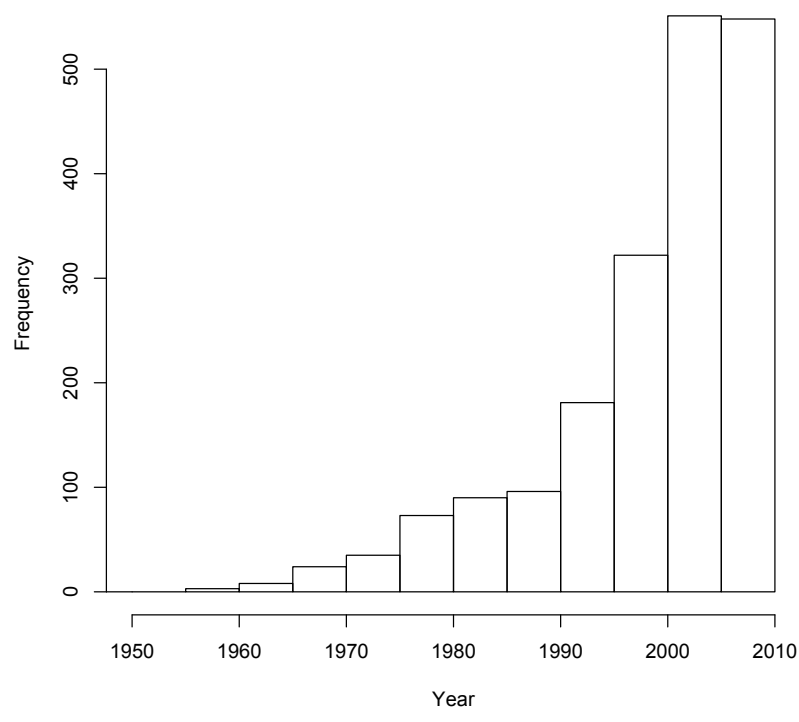

Fig. 1. Soil respiration studies over time, from the ISI Web of Science $^{\mathrm{TM}}$ database.

acquired and examined. To qualify for inclusion, a study had to report at least one of the following data:

- Annual $R_{\mathrm{S}}$ (as reported by the authors, or easily calculable from data; no minimum-measurement requirement was imposed)

- Mean seasonal $R_{\mathrm{S}}$ (as defined and reported by the authors)

- Annual or seasonal partitioning of $R_{\mathrm{S}}$ sources (based on field measurements; regression approaches based on other studies, e.g., Subke et al. (2006) were not allowed)

- $\mathrm{Q}_{10}$ and associated temperature range

- $\mathrm{R}_{10}\left(R_{\mathrm{S}}\right.$ at $\left.10^{\circ} \mathrm{C}\right)$

If at least one of these data was reported, or could be calculated with few or no assumptions, e.g., straightforwardly estimated from points in a figure, the study was entered into the database. Short-term experiments (i.e., $R_{\mathrm{S}}$ measurements made over less than 1-2 weeks) were not entered unless the study authors extrapolated their results to seasonal or annual values; the database's orientation is thus to seasonal and annual fluxes, not shorter-term or chamber-specific measurements. Annual fluxes were sometimes reported by authors, and in other cases calculated from sub-annual (e.g., monthly) means. In general we did not do additional research to find older publications that might not be listed in the Web of Science.

\subsection{Database structure}

The database ("SRDB") is composed of two separate data files: a "studies" file, listing the publication information for 
all studies acquired, examined, entered or rejected, etc., and a "data" file, holding the acquired $R_{\mathrm{S}}$ data. An index number is used to map entries between the two files. The primary $R_{\mathrm{S}}$ units used were $\mathrm{g} \mathrm{C} \mathrm{m}^{-2} \mathrm{yr}^{-1}$ (for annual fluxes) and $\mu \mathrm{mol} \mathrm{m} \mathrm{m}^{-2} \mathrm{~s}^{-1}$ (for mean seasonal and $R_{10}$ fluxes); values were converted as necessary from those given by study authors. A variety of ancillary data were also entered when reported, including site-related and experimental data, information on ecosystem structure and function, methods used, etc.; we assumed a 12:44 ratio of $\mathrm{C}$ to $\mathrm{CO}_{2}$ molecular weights, and that biomass was $50 \% \mathrm{C}$ (unless specified otherwise in the study). Temperate-response functions were categorized following table 10.1 in Luo and Zhou. (Luo and Zhou, 2006) and Reichstein et al. (2008). The primary data file includes 105 fields (Table 1). A Google Earth (http: //earth.google.com/) data layer is included with the database for easy geographic visualization of the included studies.

\subsection{Quality control}

Some basic quality control has been performed on the data. Map plots were used to identify incorrectly entered location or climate information, and histograms of the primary variables of interest used to flag outliers for special attention. We have also attempted to check for basic data incompatibilities (e.g., cases where $R_{\mathrm{S}}>$ total ecosystem respiration), and to identify duplicate entries. In addition, the database has fields documenting the chamber and $\mathrm{CO}_{2}$ measurement method employed; methodological errors associated with such techniques can have important implications for field measurements (Keith and Wong, 2006; Pongracic et al., 1997; Pumpanen et al., 2004) and upscaling of fluxes (Reichstein and Beer, 2008). In spite of these efforts, many errors undoubtedly remain in the database (see Sect. 4.2 below).

Several metadata fields (field 6 in Table 1) are used to flag duplicate records, or ones with potential problems. In retrospect we wish that these metadata were even more extensive, recording, e.g., exactly how annual fluxes were calculated for each record, as such metadata constitute a critical means of filtering data and testing how assumptions affect the end data products. Certainly any use of the existing database needs to account carefully for known quality control issues along with the recorded measurement conditions (e.g., any manipulations performed, or $\mathrm{CO}_{2}$ measurement technique used).

\section{Results and discussion}

In total, 1932 studies were marked for acquisition, 1853 acquired and examined, and 818 entered into the SRDB database, spanning the publication years 1963-2008 and measurement years 1961-2007. As of this writing the 818 studies resulted in 3379 records (a single study generates multiple records if, e.g., there are multiple years of data, or different sites reported, or different experimental treatments). The countries most frequently represented include USA (1404 records), Canada (308), China (273), Finland (179), Japan (162) and Germany (115); Figure 2 shows the spatial distribution of the collected data. Temperate-biome studies dominate the database (2373 records), with boreal (415) and tropical (353) also significant. While spatially clumped, the data cover the terrestrial climate space fairly completely (Fig. 3). Data from forest (2198 records), grassland (460) and agricultural (453) ecosystems are most frequently reported; upland systems (3084 records) far outnumber wetland ones. A majority of studies took place in unmanipulated ecosystems (2382 records), but data from thinned, burned, $\mathrm{CO}_{2}$-increase, warmed and fertilized plots are represented as well.

Below we outline, rather than analyze in depth, a few characteristics of the SRDB data and suggest some lines of research that could be explored using these data.

\subsection{Observed annual fluxes}

Mean ( \pm 1 s.d.) annual $R_{\mathrm{S}}$ was $109 \pm 109,383 \pm 228$, $745 \pm 421,813 \pm 436,776 \pm 380$, and $1286 \pm 633 \mathrm{~g} \mathrm{C} \mathrm{m}^{-2}$ for unmanipulated Arctic, boreal, temperate, Mediterranean, subtropical, and tropical ecosystems respectively. The tropical data are near-normally distributed, while boreal and temperate data are not (Fig. 4); this reflects the zero-bound of annual $R_{\mathrm{S}}$ (it is not normally negative) in ecosystems limited by low temperatures. Three variables - mean annual temperature, precipitation, and leaf area index, when combined in a simple linear regression analysis - explain $\sim 41 \%$ of the observed variability in annual $R_{\mathrm{S}}$, in line with previous meta-analyses of these drivers (Raich and Schlesinger, 1992; Reichstein et al., 2003). The annual data also exhibited an increasing temporal trend, driven primarily by air temperature anomaly (Bond-Lamberty and Thomson, 2010). Annual fluxes were correlated with other $\mathrm{C}$ fluxes (Fig. 5); such relationships have been noted in previous studies, e.g., that between litterfall and $R_{\mathrm{S}}$ (Raich and Nadelhoffer, 1989; Raich and Schlesinger, 1992; Davidson et al., 2002) or gross primary production and $R_{\mathrm{S}}$ (Hibbard et al., 2005; Janssens et al., 2001). The correlations shown in Fig. 5 (and Fig. 6 below) are relatively crude and did not vary by ecosystem type -i.e., between forests, grasslands, etc. - in spite of the significantly variation in biotic and abiotic controls that would be expected. More sophisticated analyses, e.g. machine learning or other stratified regression techniques (Jung et al., 2009), might be profitably applied to this problem.

An interesting question is how to rank the importance of various ancillary data when measuring $R_{\mathrm{S}}$ (Wayson et al., 2006). Many studies have attempted to regress $R_{\mathrm{S}}$ against a wide range of biotic and abiotic variables, but the results vary tremendously across ecosystems and biomes (Del Grosso et al., 2005; Raich and Schlesinger, 1992; Reichstein et al., 2003). These correlations also raise the possibility 
Table 1. Categories of database fields and examples of data included for the soil respiration $\left(R_{\mathrm{S}}\right)$ database's main "data" file. A separate "studies" file contains bibliographic information for all studies, indexed by a study number common to both files.

\begin{tabular}{|c|c|c|}
\hline Num & Field name & Description \\
\hline \multicolumn{3}{|c|}{ Metadata } \\
\hline 1 & Record_number & Record number \\
\hline 2 & Entry_date & Entry date \\
\hline 3 & Study_number & Study number; index into the studies database \\
\hline 4 & Author & Name of first author \\
\hline 5 & Duplicate_record & Is record a known duplicate? (Study number) \\
\hline 6 & Quality_flag & $\begin{array}{l}\text { Quality control. Quality control flags include Q0 (default/none), Q01 (es- } \\
\text { timated from figure), Q02 (data from another study), Q03 (data estimated- } \\
\text { other), Q04 (potentially useful future data), Q10 (potential problem with } \\
\text { data), Q11 (suspected problem with data), Q12 (known problem with data), } \\
\text { Q13 (duplicate?), Q14 (inconsistency). Further details can generally be } \\
\text { found in the notes field (\#105 below) }\end{array}$ \\
\hline 7 & Contributor & Data contributor \\
\hline \multicolumn{3}{|c|}{ Site and measurement data } \\
\hline 8 & Country & Country \\
\hline 9 & Region & State/province/region \\
\hline 10 & Site_name & Name of study site \\
\hline 11 & Study_midyear & Year study was performed (middle year if multiple years) \\
\hline 12 & YearsOfData & Years of data; always $\geq 1$ \\
\hline 13 & Latitude & Latitude, decimal; positive $=$ north, negative $=$ south \\
\hline 14 & Longitude & Longitude, decimal; positive $=$ east, negative $=$ west \\
\hline 15 & Elevation & Elevation, $\mathrm{m}$ \\
\hline 16 & Manipulation & Manipulation performed $\left(\mathrm{CO}_{2}\right.$, fertilization, etc. $)$ \\
\hline 17 & Manipulation_level & Degree of manipulation performed \\
\hline 18 & Age_ecosystem & $\begin{array}{l}\text { Time since ecosystem established, years. This is used when, e.g., the time } \\
\text { of conversion of forest to agriculture is known }\end{array}$ \\
\hline 19 & Age_disturbance & Time since disturbance, years \\
\hline 20 & Species & Dominant species \\
\hline 21 & Biome & Biome (boreal, temperate, etc). Subjective \\
\hline 22 & Ecosystem_type & Ecosystem type (grassland, forest, etc). Subjective \\
\hline 23 & Ecosystem_state & $\begin{array}{l}\text { Ecosystem state (managed, unmanaged, natural). Subjective. "Unmanaged" } \\
\text { means human management or disturbance in the past, but not currently. }\end{array}$ \\
\hline 24 & Leaf_habit & Dominant leaf habit (deciduous, evergreen) \\
\hline 25 & Stage & Developmental stage (aggrading, mature). Subjective \\
\hline 26 & Soil_type & Soil description (classification and texture) \\
\hline 27 & Soil_drainage & $\begin{array}{l}\text { Soil drainage (dry, wet). Subjective. "Dry" means well-drained uplands; } \\
\text { "wet" peatlands, swamps, etc. }\end{array}$ \\
\hline 28 & Soil_BD & Soil bulk density, $\mathrm{g} \mathrm{cm}^{-3}$ \\
\hline 29 & Soil_CN & Soil C:N ratio \\
\hline 30 & Soil_sandsiltclay & Soil sand:silt:clay ratio \\
\hline 31 & MAT & Reported mean annual temperature,${ }^{\circ} \mathrm{C}$ \\
\hline 32 & MAP & Reported mean annual precipitation, $\mathrm{mm}$ \\
\hline 33 & PET & Reported potential evapotranspiration, $\mathrm{mm}$ \\
\hline 34 & Study_temp & Annual temperature in year of study, ${ }^{\circ} \mathrm{C}$ \\
\hline 35 & Study_precip & Annual precipitation in year study of study, $\mathrm{mm}$ \\
\hline 36 & Chamber_method & Chamber method \\
\hline 37 & CO2_method & $\mathrm{CO}_{2}$ measurement method \\
\hline 38 & Partition_method & $\begin{array}{l}\text { Method used to partition } R_{\mathrm{S}} \text { source fluxes, following Bond-Lamberty et } \\
\text { al. (2004) }\end{array}$ \\
\hline
\end{tabular}


Table 1. Continued.

\begin{tabular}{|c|c|c|}
\hline \multicolumn{3}{|c|}{ Annual and seasonal $R_{\mathrm{S}}$ fluxes } \\
\hline 39 & Rs_annual & $\begin{array}{l}\text { Annual } \mathrm{C} \text { flux from soil respiration, } \mathrm{g} \mathrm{C}^{-2} \text {. This can either be reported } \\
\text { directly by the study, calculated from reported mean fluxes, or estimated } \\
\text { from a figure (in which case a quality control note is made, field } 6 \text { ) }\end{array}$ \\
\hline 40 & Rs_annual_err & Error (typically plot-to-plot) for Rs_annual, $\mathrm{g} \mathrm{C} \mathrm{m}^{-2}$ \\
\hline 41 & Rs_interann_err & $\begin{array}{l}\text { Interannual error reported for Rs_annual, } \mathrm{g} \mathrm{C}^{-2} \text {. This is occasionally re- } \\
\text { ported by authors, or defined as the standard deviation between year } i \text { and } \\
\text { year } i+1(N=2)\end{array}$ \\
\hline 42 & Rs_max & Maximum $R_{\mathrm{S}}$ flux, $\mu \mathrm{mol} \mathrm{m}{ }^{-2} \mathrm{~s}^{-1}$ \\
\hline 43 & Rs_maxday & Maximum $R_{\mathrm{S}}$ flux day of year \\
\hline 44 & Rs_min & Minimum $R_{\mathrm{S}}$ flux, $\mu \mathrm{mol} \mathrm{m}{ }^{-2} \mathrm{~s}^{-1}$ \\
\hline 45 & Rs_minday & Minimum $R_{\mathrm{S}}$ flux day of year \\
\hline 46 & Rlitter_annual & Annual $R_{\mathrm{S}}$ flux from litter, $\mathrm{g} \mathrm{C} \mathrm{m}^{-2}$ \\
\hline 47 & Ra_annual & Annual autotrophic $R_{\mathrm{S}}$ flux, $\mathrm{g} \mathrm{C} \mathrm{m}^{-2}$ \\
\hline 48 & Rh_annual & Annual heterotrophic $R_{\mathrm{S}}$ flux, $\mathrm{g} \mathrm{C} \mathrm{m}^{-2}$ \\
\hline 49 & RC_annual & Root contribution to Rs_annual, annual fraction \\
\hline 50 & Rs_spring & Mean spring $R_{\mathrm{S}}$ flux, $\mu \mathrm{mol} \mathrm{m} \mathrm{m}^{-2} \mathrm{~s}^{-1}$. Seasons are defined by authors \\
\hline 51 & Rs_summer & Mean summer $R_{\mathrm{S}}$ flux, $\mu \mathrm{mol} \mathrm{m}{ }^{-2} \mathrm{~s}^{-1}$ \\
\hline 52 & Rs_autumn & Mean autumn $R_{\mathrm{S}}$ flux, $\mu \mathrm{mol} \mathrm{m}{ }^{-2} \mathrm{~s}^{-1}$ \\
\hline 53 & Rs_winter & Mean winter $R_{\mathrm{S}}$ flux, $\mu \mathrm{mol} \mathrm{m}{ }^{-2} \mathrm{~s}^{-1}$ \\
\hline 54 & Rs_growingseason & Mean growing $R_{\mathrm{S}}$ flux, $\mu \mathrm{mol} \mathrm{m}{ }^{-2} \mathrm{~s}^{-1}$ \\
\hline 55 & Rs_wet & Mean wet season $R_{\mathrm{S}}$ flux, $\mu \mathrm{mol} \mathrm{m}{ }^{-2} \mathrm{~s}^{-1}$ \\
\hline 56 & Rs_dry & Mean dry season $R_{\mathrm{S}}$ flux, $\mu \mathrm{mol} \mathrm{m}{ }^{-2} \mathrm{~s}^{-1}$ \\
\hline 57 & RC_seasonal & Root contribution to seasonal $R_{\mathrm{S}}$, fraction \\
\hline 58 & RC_season & Season of RC_seasonal \\
\hline \multicolumn{3}{|c|}{ Response of $R_{\mathrm{S}}$ to temperature and moisture } \\
\hline 59 & Model_type & Type of temperature-response model used \\
\hline 60 & Temp_effect & Temperature effect on $R_{\mathrm{S}}$ (none, positive, negative) \\
\hline 61 & Model_output_units & Temperature-response model output units \\
\hline 62 & Model_temp_range & Soil temperature range over which model fitted \\
\hline 63 & Model_N & Model N \\
\hline 64 & Model_R2 & Model r-squared \\
\hline 65 & T_depth & $\begin{array}{l}\text { Depth at which soil temperature recorded, } \mathrm{cm} \text {. A value of }-200 \text { (i.e., } 2 \mathrm{~m} \\
\text { above ground) is used for air temperature }\end{array}$ \\
\hline $66-70$ & Model_paramA... & Model parameters (A-E) \\
\hline 71 & WC_effect & Soil water effect on $R_{\mathrm{S}}$ \\
\hline 72 & $\mathrm{R} 10$ & $R_{\mathrm{S}}$ at $10^{\circ} \mathrm{C}, \mu \mathrm{mol} \mathrm{m}-2 \mathrm{~s}^{-1}$ \\
\hline $73-80$ & $\mathrm{Q}_{10} \cdots$ & $\begin{array}{l}\mathrm{Q}_{10} \text { temperature responses, for } 0-10,5-15,10-20,0-20^{\circ} \mathrm{C} \text {, as well as cus- } \\
\text { tom ranges. } \mathrm{Q}_{10} \text { values are either reported by authors, calculated from re- } \\
\text { ported } R_{\mathrm{S}} \text {-temperature regressions, or occasionally estimated from figures } \\
\text { (in which case a quality control note is made, field } 6 \text { ) }\end{array}$ \\
\hline
\end{tabular}

of estimating $R_{\mathrm{S}}$, with an associated error range, from airborne and satellite observations; the lack of such large-scale, observation-driven $R_{\mathrm{S}}$ estimates is a major problem in constraining regional- to global-scale C fluxes (Qi et al., 2002; Rayner et al., 2005; Jones et al., 2003).

\subsection{Experimental error and $\boldsymbol{R}_{\mathrm{S}}$ variability}

The high variability of $R_{\mathrm{S}}$ constitutes a major reason why its measurement and modeling remain so difficult, as it responds to a suite of drivers including temperature, moisture, and vegetation productivity, all at different spatial and temporal scales (Reichstein et al., 2003; Rochette et al., 1991; Rodeghiero and Cescatti, 2008; Saiz et al., 2006; Vincent et al., 2006; Webster et al., 2008). Two measures of variability (fields 40-41 in Table 1) are defined in the SRDB: interannual variability (the standard deviation of a series of annual $R_{\mathrm{S}}$ values, all measured at one place) and error of the annual flux (typically plot-to-plot error, i.e., the standard deviation of a group of concurrently-measured values); few studies report both (Kabwe et al., 2005). The former is either 
Table 1. Continued.

\begin{tabular}{|c|c|c|}
\hline \multicolumn{3}{|c|}{ Ancillary pools and fluxes } \\
\hline 81 & GPP & Annual gross primary production at site, $\mathrm{g} \mathrm{C} \mathrm{m}^{-2}$ \\
\hline 82 & ER & Annual ecosystem respiration at site, $\mathrm{g} \mathrm{C} \mathrm{m}^{-2}$ \\
\hline 83 & NEP & Annual net ecosystem production at site, $\mathrm{g} \mathrm{C} \mathrm{m}^{-2}$ \\
\hline 84 & NPP & Annual net primary production at site, $\mathrm{g} \mathrm{C} \mathrm{m}^{-2}$ \\
\hline 85 & ANPP & Annual aboveground NPP at site, $\mathrm{g} \mathrm{C} \mathrm{m}^{-2}$ \\
\hline 86 & BNPP & Annual belowground NPP at site, $\mathrm{g} \mathrm{C} \mathrm{m}^{-2}$ \\
\hline 87 & NPP_FR & Annual fine root NPP at site, $\mathrm{g} \mathrm{C} \mathrm{m}^{-2}$ \\
\hline 88 & TBCA & Total belowground carbon allocation at site, $\mathrm{g} \mathrm{C} \mathrm{m}^{-2}$ \\
\hline 89 & Litter_flux & $\begin{array}{l}\text { Annual aboveground litter flux, } \mathrm{g} \mathrm{C}^{-2} \text {. This is reported very inconsis- } \\
\text { tently (leaf only, leaf and fine woody material, all material, etc). Generally } \\
\text { this should not include large woody material }\end{array}$ \\
\hline 90 & Rootlitter_flux & Annual belowground litter flux, $\mathrm{g} \mathrm{C} \mathrm{m}^{-2}$ \\
\hline 91 & TotDet_flux & $\begin{array}{l}\text { Annual total litter flux, } \mathrm{g} \mathrm{C} \mathrm{m}^{-2} \text {. This should be the sum of Litter_flux and } \\
\text { Rootlitter_flux }\end{array}$ \\
\hline 92 & Ndep & Annual nitrogen deposition, $\mathrm{g} \mathrm{N} \mathrm{m}^{-2}$ \\
\hline 93 & CH4_flux & Annual methane flux, $\mathrm{g} \mathrm{C} \mathrm{m}^{-2}$ \\
\hline 94 & N2O_flux & Annual nitrous oxide flux, $\mathrm{g} \mathrm{N} \mathrm{m}^{-2}$ \\
\hline 95 & LAI & Leaf area index at site, $\mathrm{m}^{2} \mathrm{~m}^{-2}$. Hemispheric (one-sided) if possible \\
\hline 96 & BA & Basal area at site, $\mathrm{m}^{2} \mathrm{ha}^{-1}$ \\
\hline 97 & C_veg_total & $\begin{array}{l}\text { Total carbon in vegetation, } \mathrm{g} \mathrm{C} \mathrm{m}^{-2} \text {. This should be the sum of } \mathrm{C} \_\mathrm{AG} \text { and }_{\mathrm{C}} \text {.BG. For this and all "C_" fields, biomass is converted to carbon using a } \\
\text { ratio of } 0.5 \text { unless study-specific values are available }\end{array}$ \\
\hline 98 & C_AG & Total carbon in aboveground vegetation, $\mathrm{g} \mathrm{C} \mathrm{m}^{-2}$ \\
\hline 99 & C_BG & Total carbon in belowground vegetation, $\mathrm{g} \mathrm{C} \mathrm{m}^{-2}$ \\
\hline 100 & C_CR & Total carbon in coarse roots, $\mathrm{g} \mathrm{C} \mathrm{m}^{-2}$ \\
\hline 101 & C_FR & Total carbon in fine roots, $\mathrm{g} \mathrm{C} \mathrm{m}^{-2}$ \\
\hline 102 & C_litter & Total carbon in standing litter, $\mathrm{g} \mathrm{C} \mathrm{m}^{-2}$ \\
\hline 103 & C_soil & Total carbon in soil organic matter, $\mathrm{g} \mathrm{C} \mathrm{m}^{-2}$ \\
\hline 104 & C_soildepth & Depth to which soil C recorded, $\mathrm{cm}$ \\
\hline \multicolumn{3}{|c|}{ Other } \\
\hline 105 & Notes & Notes \\
\hline
\end{tabular}

reported by study authors or calculated within the database from individual year data. The mean coefficient of variability (standard deviation divided by the mean) in the SRDB is 15$16 \%$ for both variables. Ecosystem variability does not scale linearly to regional or global variability, and estimates of the interannual variability of large-scale $R_{\mathrm{S}}$ fluxes are much smaller than these means (Potter and Klooster, 1998; Raich et al., 2002; Bond-Lamberty and Thomson, 2010).

\subsection{Temperature sensitivity}

Ambient temperature constitutes the dominant - but not only - short-term control on $R_{\mathrm{S}}$ in most boreal and temperate ecosystems, at most points in time (Chen and Tian, 2005); temperate deserts and other dry areas constitute only one of many exceptions to this generalization (Parker et al., 1983; Zhou et al., 2009; Sponseller and Fisher, 2008; Tang et al., 2005). Our understanding of $R_{\mathrm{S}}$ and ecosystem respiration generally (Trumbore, 2006) is less advanced than that of pho- tosynthesis, and most biogeochemical models still use simple, constant- $\mathrm{Q}_{10}$ models (originating from van't Hoff, 1898) that - among other problems - have been shown to overestimate low-temperature $R_{\mathrm{S}}$ (Lloyd and Taylor, 1994).

An interesting question to which the SRDB could be applied is how $R_{\mathrm{S}}$ temperature sensitivity changes with temperature, and whether a general temperature-dependent model exists for $R_{\mathrm{S}}$; if this is the case, most large-scale $R_{\mathrm{S}}$ models, which use a constant $\mathrm{Q}_{10}$ response, could be shown to be considerably biased, (Chen and Tian, 2005; Tjoelker et al., 2001). The SRDB records the temperature-response model used by individual studies as well as $\mathrm{Q}_{10}$ values (the relative $R_{\mathrm{S}}$ change over $10^{\circ} \mathrm{C}$ ) for a variety of temperature ranges, as this parameter is reported so frequently in the $R_{\mathrm{S}}$ literature. Mean $\mathrm{Q}_{10}$ values in the database are $3.3 \pm 1.5$ for $0-10{ }^{\circ} \mathrm{C}, 2.9 \pm 1.2$ for $5-15^{\circ} \mathrm{C}, 2.6 \pm 1.1$ for $10-20^{\circ} \mathrm{C}$, and $3.0 \pm 1.1$ over the entire $0-20^{\circ} \mathrm{C}$ range; these means exclude a few extreme $\left(\mathrm{Q}_{10} \geq 10, \sim 1 \%\right.$ of the data) reported values. These values must be treated with caution: these values 


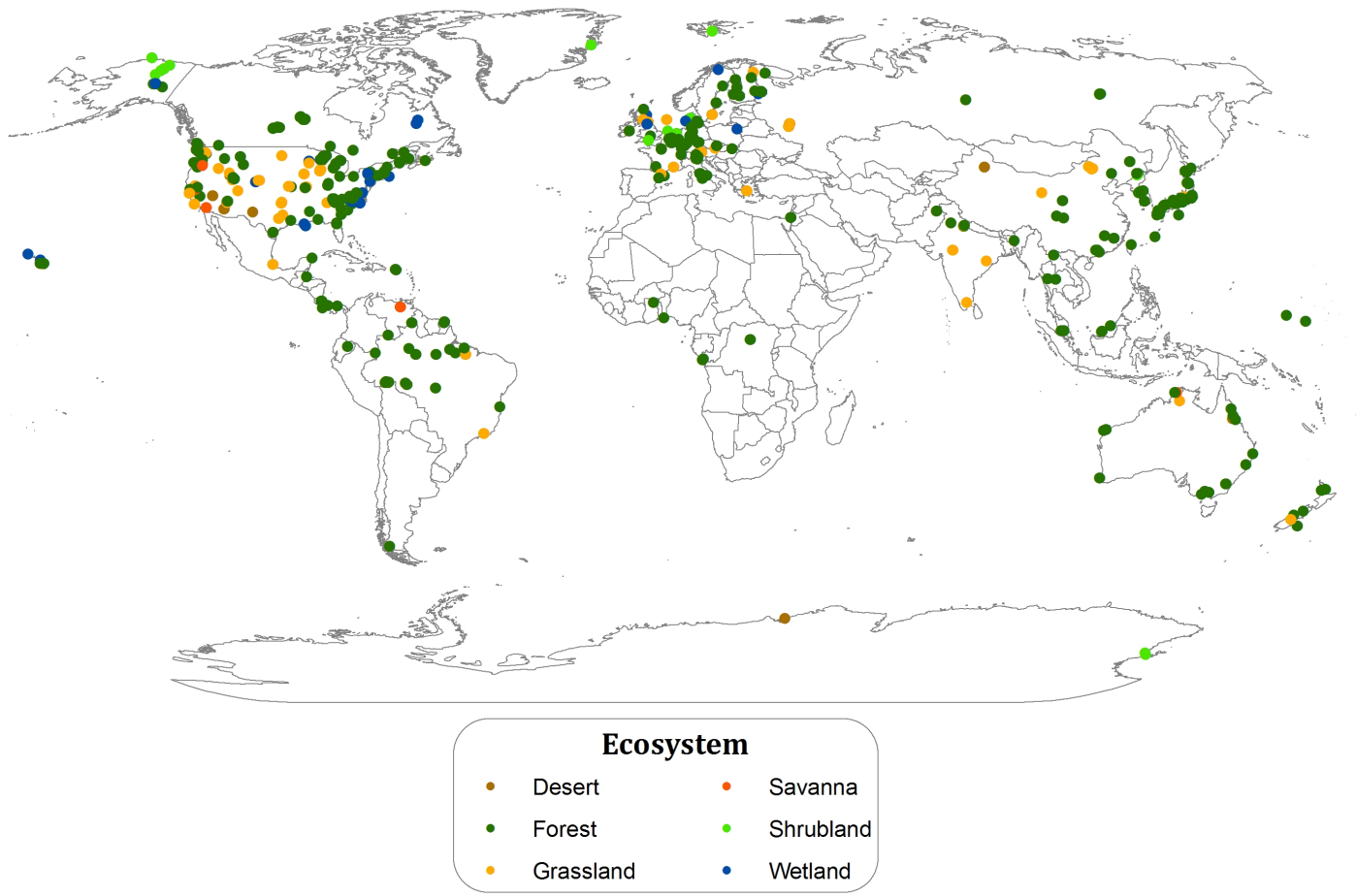

Fig. 2. Location of SRDB database observations (dots), by ecosystem type. A Google Earth ${ }^{\mathrm{TM}}$ data layer is included with the database for more detailed spatial views.

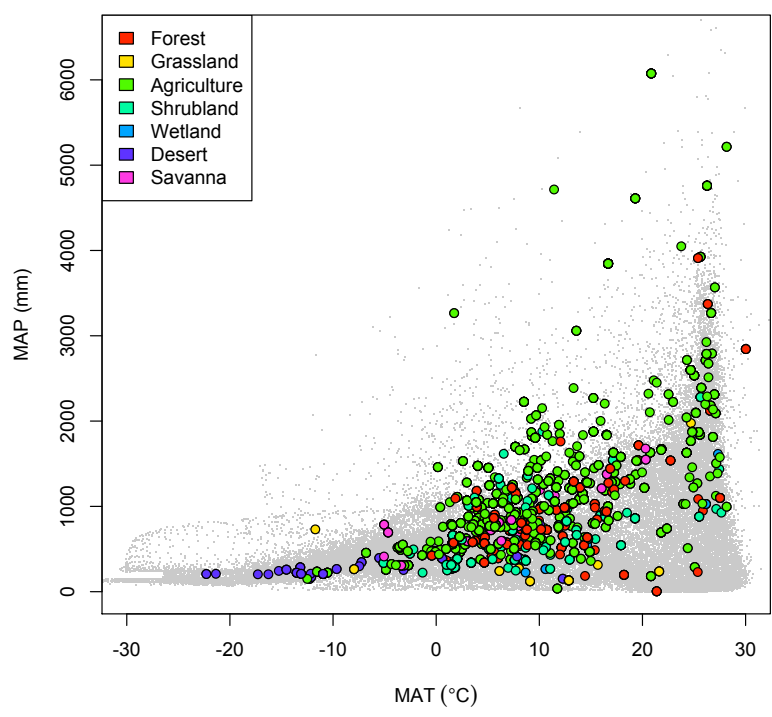

Fig. 3. SRDB data distribution across global mean annual temperature (MAT) and mean annual precipitation (MAP) climate space, by ecosystem type. Background dots show climate distribution of terrestrial surface $\left(0.5^{\circ}\right.$ cells $)$.

are "apparent" (Davidson and Janssens, 2006) temperature sensitivities, as they are observed in the field and thus constrained by ambient environmental conditions (Zhou et al., 2009), rather than "intrinsic" or theoretical sensitivities; in

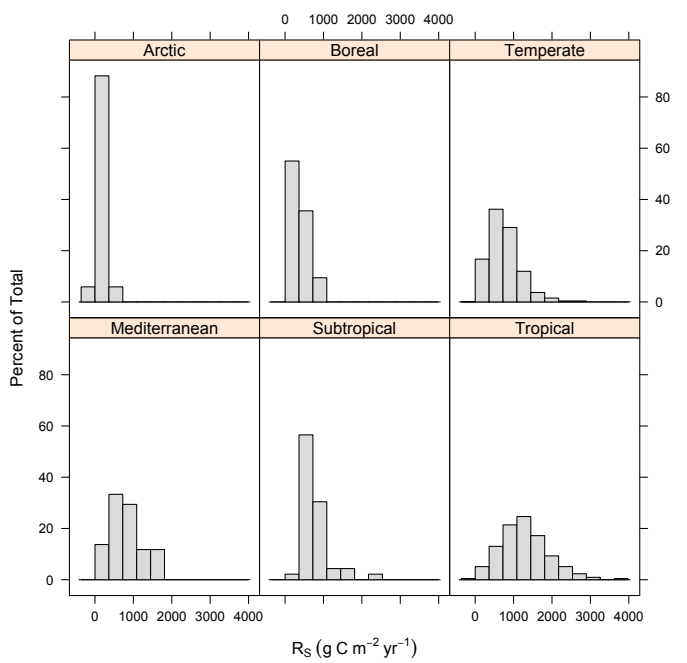

Fig. 4. Annual soil respiration $\left(R_{\mathrm{S}}\right)$ fluxes observed in the field, unmanipulated plots only, by biome. Relative histograms are shown; total observations are $N=17,180,1053,51,46$, and 215 for Arctic, boreal, temperate, Mediterranean, subtropical, and tropical respectively.

addition, they are not based on a statistically random sample. Nonetheless these data should be of use for further explorations of how soil and air temperatures affect on $\mathrm{Q}_{10}$ variability (Chen and Tian, 2005). 

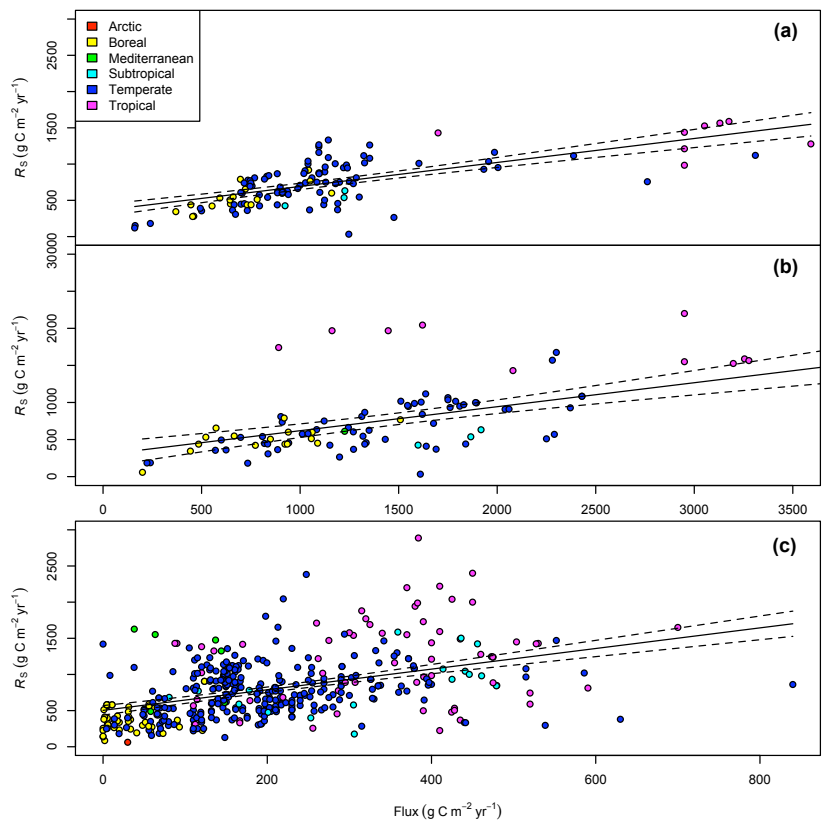

Fig. 5. Correlation between annual soil respiration $\left(R_{\mathrm{S}}\right)$ and other carbon fluxes: (a) annual ecosystem respiration, (b) annual gross primary production, and (c) annual aboveground litter flux, by biome. Solid lines show linear regression fit; dashed lines are 95\% confidence intervals. Regressions shown are (a) $y=361+0.33 x$, $N=116, R^{2}=0.48$; (b) $y=296+0.32 x, N=92, R^{2}=0.33$; (c) $y=502+1.43 x, N=421, R^{2}=0.21$.

Reported $\mathrm{Q}_{10}$ values for $R_{\mathrm{S}}$ depend strongly on the depth at which the temperature measurement is made (Reichstein and Beer, 2008; Graf et al., 2008), as well as the observed temperature range. The current database structure includes a field for recording this depth datum, and is flexible enough to accommodate multiple depths of measurement. If a study reported a variety of $\mathrm{Q}_{10}$ values across multiple depths, these are not always all measured, as we focused on typical measurement depths $(0-20 \mathrm{~cm})$. This is an obvious area for future improvement.

\subsection{Source fluxes of soil respiration}

Partitioning $R_{\mathrm{S}}$ into its autotrophic $\left(R_{\mathrm{A}}\right)$ and heterotrophic $\left(R_{\mathrm{H}}\right)$ source fluxes is important for assessing plant physiology, $\mathrm{C}$ allocation, ecosystem $\mathrm{C}$ balance, and the climate feedback potential of changes in $R_{\mathrm{S}}$. The relative responses of $R_{\mathrm{A}}$ and $R_{H}$ will strongly affect the terrestrial climate feedback under future conditions, at scales from the ecosystem to the globe (Burton et al., 2008; Boone et al., 1998; Curiel Yuste et al., 2007; Lavigne et al., 2003). Broad means have been computed for the relative contribution of $R_{\mathrm{S}}$ source fluxes (Hanson et al., 2000); in addition, Bond-Lamberty et al. (2004) noted a highly significant $\left(R^{2}=0.8, P<0.001\right)$ relationship between $R_{\mathrm{S}}$ and $R_{\mathrm{H}}$, permitting the estimation of the latter from annual estimates of the former. The much larger data set collected here allows us to re-examine this relationship

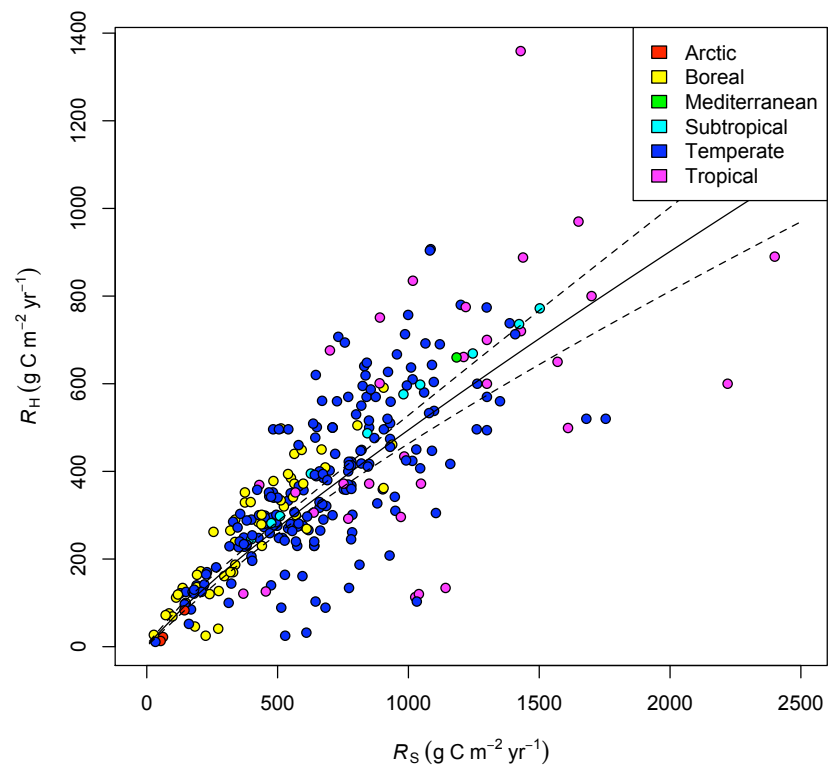

Fig. 6. Relationship between soil respiration $\left(R_{\mathrm{S}}\right)$ and heterotrophic soil respiration $\left(R_{\mathrm{H}}\right)$ in the database, by biome, following Bond-Lamberty et al. (2004). Fitted model shown (solid line) is $\ln \left(R_{\mathrm{H}}\right)=0.22+0.87 \ln \left(R_{\mathrm{S}}\right), R^{2}=0.64, P<0.001$; dashed lines show 95\% confidence interval. Two studies (Grier and Logan, 1977; Thierron and Laudelout, 1996) in the database were excluded from this figure based on a Cook's influential outlier test (R Development Core Team, 2009).

(Fig. 6); it remains fundamentally the same as that found in Bond-Lamberty et al. (2004), although these data show considerably more scatter. We also note that a few studies examine mycorrhizal (Moyano et al., 2007; Heinemeyer et al., 2007) and geological (Andrews and Schlesinger, 2001) contributions to $R_{\mathrm{S}}$, although these sources are not broken out in the current database.

\section{SRDB access and future development}

The SRDB database described here is being released to the scientific community and other interested users, and is available immediately online.

\subsection{Database access and updates}

A static version of these data is permanently archived at the Oak Ridge National Laboratory's Distributed Active Archive Center (ORNL-DAAC, http://daac.ornl.gov), with a digital object identifier (DOI) of 10.3334/ORNLDAAC/984. There is also a dynamic version of the database, hosted as of this writing on Google Code (http://code.google.com/p/srdb/). This latter archive uses version control software (Subversion, http://subversion.tigris.org/), so that researchers can use (check out) current as well as previous versions of the database. It also features online wiki documentation, a mailing list, and other aspects typical of any open-source project. 
Both archives include the database itself, metadata, and usage notes. Initially the two repositories will hold identical copies, but we anticipate that the dynamic version will be expanded and change with time. (In fact it has been updated, as of mid-May 2010, with studies published in 2009.) Thus we recommend that citations to this database always include a version number, download date, and relevant URL. For the immediate future, we anticipate biannual updates to the database; ultimately the scientific community will determine how, and if, this database is used and updated.

\subsection{Weaknesses of the current database}

This database should be viewed as a "1.0" release. First, there are inevitable data entry mistakes - in unit conversion, language translation, etc. - that will be discovered and corrected. Second, data can be added: new studies appear frequently (91 studies published in 2008 alone were entered, and a similar number were published in 2009), and missed older ones found. In particular, we suspect that there is substantial data in the Russian- and Chinese-language scientific literatures not currently in SRDB. Finally, there are undoubtedly better ways to structure the existing data, and new fields or calculations could be added (for example, metainformation could be improved, as noted above; the $R_{\mathrm{S}}$ soil moisture response is only cursorily treated in the current database; no error terms are included for $\mathrm{Q}_{10}$ and $\mathrm{R}_{10}$ estimates; $R_{\mathrm{S}}$ partitioning is limited to a crude autotrophic and heterotrophic separation; $\mathrm{Q}_{10}$ estimates are not recorded separately by source flux; etc). For all these reasons, we intend to update the dynamic version of this database, and hope that such updating and corrections will ultimately become a shared project driven by interested users of these data; this will make it a true community database that over time could be linked with other, similar projects.

\section{Conclusions}

The SRDB is designed to capture and make available for analysis the large number of $R_{\mathrm{S}}$ studies published over the last four decades. It will also, we hope, be one of the first such databases in the earth sciences to leverage open-source software technologies, resulting in a dynamic, shared, and more powerful data resource for interested users. The science community will determine how, and if, it changes in the future, and the uses to which these data will be put.

Acknowledgements. This research was supported by the U.S. Department of Energy Office of Science and the Laboratory Directed Research and Development program of the Pacific Northwest National Laboratory. It would not have been possible without the thousands of researchers worldwide who measured, analyzed, and published the data collected here.

Edited by: M. Bahn

\section{References}

Andrews, J. A. and Schlesinger, W. H.: Soil $\mathrm{CO}_{2}$ dynamics, acidification, and chemical weathering in a temperate forest with experimental $\mathrm{CO}_{2}$ enrichment, Global Biogeochem. Cy. 15, 149-162, 2001.

Anonymous: Data's shameful neglect, Nature, 461, 145, doi:10.1038/461145a, 2009.

Boden, T. A., Marland, G., and Andres, R. J. Global, regional, and national fossil-fuel $\mathrm{CO}_{2}$ emissions: Oak Ridge, TN: Carbon Dioxide Information Analysis Center, ORNL, http://cdiac. ornl.gov/trends/emis/overview_2006.html, 2009.

Bond-Lamberty, B., Wang, C., and Gower, S. T.: A global relationship between the heterotrophic and autotrophic components of soil respiration?, Global Change Biol., 10, 1756-1766, doi:10.1111/j.1365-2486.2004.00816.x, 2004.

Bond-Lamberty, B. and Thomson, A. M.: Temperature-associated increases in the global soil respiration record, Nature, 464, 579582, doi:10.1038/nature08930, 2010.

Boone, R. D., Nadelhoffer, K. J., Canary, J. D., and Kaye, J. P.: Roots exert a strong influence on the temperature sensitivity of soil respiration, Nature, 396, 570-572, doi:10.1038/25119, 1998

Burton, A. J., Melillo, J. M., and Frey, S. D.: Adjustment of forest ecosystem root respiration as temperature warms, J. Integr. Plant Biol., 50, 1467-1483, doi:10.1111/j.1744-7909.2008.00750.x, 2008.

Chen, H. and Tian, H.-Q.: Does a general temperature-dependent $\mathrm{Q}(10)$ model of soil respiration exist at biome and global scale? J. Integr. Plant Biol., 47, 1288-1302, 2005.

Curiel Yuste, J., Baldocchi, D. D., Gershenson, A., Goldstein, A. H., Misson, L., and Wong, S. C.: Microbial soil respiration and its dependency on carbon inputs, soil temperature and moisture, Global Change Biol., 13, 1-18, doi:10.1111/j.13652486.2007.01415.x, 2007.

Davidson, E. A., Savage, K. E., Bolstad, P. V., Clark, D. A., Curtis, P. S., Ellsworth, D. S., Hanson, P. J., Law, B. E., Luo, Y., Pregitzer, K. S., Randolph, J. C., and Zak, D. R.: Belowground carbon allocation in forests estimated from litterfall and IRGA-based soil respiration measurements, Agric. Forest Meteorol., 113, 3951, 2002.

Davidson, E. A. and Janssens, I. A.: Temperature sensitivity of soil carbon decomposition and feedbacks to climate change, Nature, 440, 165-173, doi:10.1038/nature04514, 2006.

Davidson, E. A., Janssens, I. A., and Luo, Y.: On the variability of respiration in terrestrial ecosystems: moving beyond $\mathrm{Q}_{10}$, Global Change Biol., 12, 154-164, doi:10.1111/j.13652486.2005.01065.x, 2006.

Del Grosso, S. J., Parton, W. J., Mosier, A. R., Holland, E. A., Pendall, E., Schimel, D. S., and Ojima, D. S.: Modeling soil $\mathrm{CO}_{2}$ emissions from ecosystems, Biogeochemistry, 73, 71-91, doi:10.1007/s10533-004-0898-z, 2005.

Elser, J. J., Bracken, M. E. S., Cleland, E. E., Gruner, D. S., Harpole, W. S., Hillebrand, H., Ngai, J. T., Seabloom, E. W., Shurin, J. B., and Smith, J. E.: Global analysis of nitrogen and phosphorus limitation of primary producers in freshwater, marine and terrestrial ecosystems, Ecol. Lett., 10, 1135-1142, doi:10.1111/j.14610248.2007.01113.x, 2007.

Graf, A., Weihermúller, L., Huisman, J. A., Herbst, M., Bauer, J., and Vereecken, H.: Measurement depth effects on the apparent temperature sensitivity of soil respiration in field studies, Bio- 
geosciences, 5, 1175-1188, doi:10.5194/bg-5-1175-2008, 2008.

Grier, C. C. and Logan, R. S.: Old-growth Pseudotsuga-menziesii communities of a western Oregon watershed: biomass distribution and production budgets, Ecological Monographs, 47, 373400, 1977.

Hanson, P. J., Edwards, N. T., Garten, C. T., and Andrews, J. A.: Separating root and soil microbial contributions to soil respiration: A review of methods and observations, Biogeochemistry, 48, 115-146, doi:10.1023/A:1006244819642, 2000.

Heinemeyer, A., Hartley, I. P., Evans, S. P., Carreira de la Fuente, J. A., and Ineson, P.: Forest soil $\mathrm{CO}_{2}$ flux: uncovering the contribution and environmental responses of ectomycorrhizas, Global Change Biol., 13, 1786-1797, doi:10.1111/j.13652486.2007.01383.x, 2007.

Hibbard, K. A., Law, B. E., and Sulzman, J.: An analysis of soil respiration across northern hemisphere temperate ecosystems, Biogeochemistry, 73, 29-70, doi:10.1007/s10533-004-2946-0, 2005

IPCC: Climate Change 2001: The Science of Climate Change. Contribution of Working Group I to the Second Assessment Report of the Intergovernmental Panel on Climate Change, Cambridge Univ. Press, Cambridge, 20, 2001.

IPCC: Summary for Policymakers, in: Climate Change 2007: The Physical Science Basis. Contribution of Working Group I to the Fourth Assessment Report of the Intergovernmental Panel on Climate Change, edited by: Solomon, S. D., Qin, D., Manning, M. R., Chen, Z., Marquis, M., Averyt, K. B., Tignor, M., and Miller, H. L., Cambridge University Press, Cambridge, UK and New York, NY, USA, 18, 2007.

Janssens, I. A., Lankreijer, H., Matteucci, G., Kowalski, A. S., Buchmann, N., Epron, D., Pilegaard, K., Kutsch, W. L., Longdoz, B., Grünwald, T., Montagnani, L., Dore, S., Rebmann, C., Moors, E. J., Grelle, A., Rannik, Ü., Morgenstern, K., Oltchev, S., Clement, R., Gudmundsson, J., Minerbi, S., Berbigier, P., Ibrom, A., Moncrieff, J. B., Aubinet, M., Bernhofer, C., Jensen, N.-O., Vesala, T., Granier, A., Schulze, E.-D., Lindroth, A., Dolman, A. J., Jarvis, P. G., Ceulemans, R., and Valentini, R.: Productivity overshadows temperature in determining soil and ecosystem respiration across European forests, Global Change Biol., 7, 269-278, 2001.

Jenkinson, D. S.: Model estimates of $\mathrm{CO}_{2}$ emissions from soil in response to warming, Nature, 351, 304-306, doi:10.1038/351304a0, 1991

Jones, C. D., Cox, P. M., and Huntingford, C.: Uncertainty in climate-carbon-cycle projections associated with the sensitivity of soil respiration to temperature, Tellus, 55B, 642-648, 2003.

Jung, M., Reichstein, M., and Bondeau, A.: Towards global empirical upscaling of FLUXNET eddy covariance observations: validation of a model tree ensemble approach using a biosphere model, Biogeosciences, 6, 2001-2013, doi:10.5194/bg-6-20012009, 2009.

Kabwe, L. K., Farrell, R. E., Carey, S. K., Hendry, M. J., and Wilson, G. W.: Characterizing spatial and temporal variations in $\mathrm{CO}_{2}$ fluxes from ground surface using three complimentary measurement techniques, J. Hydrol., 311, 80-90, doi:10.1016/j.jhydrol.2004.12.015 2005.

Keith, H. and Wong, S. C.: Measurement of soil $\mathrm{CO}_{2}$ ef?ux using soda lime absorption: both quantitative and reliable Soil Biol. Biochem., 38, 1121-1131, doi:10.1016/j.soilbio.2005.09.012,
2006.

Knorr, W., Prentice, I. C., House, J. I., and Holland, E. A.: Longterm sensitivity of soil carbon turnover to warming, Nature, 433, 298-301, 2005.

Lavigne, M. B., Boutin, R., Foster, R. J., Goodine, G., Bernier, P. Y., and Robitaille, G.: Soil respiration responses to temperature are controlled more by roots than by decomposition in balsam fir ecosystems, Can. J. For. Res., 33, 1744-1753, doi:10.1139/X03090, 2003.

LeBauer, D. S. and Treseder, K. K.: Nitrogen limitation of net primary productivity in terrestrial ecosystems is globally distributed, Ecology, 89, 371-379, 2008.

Lloyd, J. and Taylor, J. A.: On the temperature dependence of soil respiration, Functional Ecology, 8, 315-323, 1994.

Luo, Y. and Zhou, X.: Soil Respiration and the Environment, Elsevier/Academic Press, Amsterdam, 316 pp., 2006.

Lusk, C. H., and Warton, D. I.: Global meta-analysis shows that relationships of leaf mass per area with species shade tolerance depend on leaf habit and ontogeny, New Phytol., 176, 764-774, doi:10.1111/j.1469-8137.2007.02264.x, 2007.

Luyssaert, S., Inglima, I., Jung, M., Richardson, A. D., Reichstein, M., Papale, D., Piao, S., Schulze, E.-D., Wingate, L., Matteucci, G., Aragão, L. E. O. C., Aubinet, M., Beer, C., Bernhofer, C., Black, K. G., Bonal, D., Bonnefond, J.-M., Chambers, J. L., Ciais, P., Cook, B. D., Davis, K. J., Dolman, A. J., Gielen, B., Goulden, M. L., Grace, J., Granier, A., Grelle, A., Griffis, T. J., Grünwald, T., Guidolotti, G., Hanson, P. J., Harding, R. B., Hollinger, D. Y., Hutyra, L. R., Kolari, P., Kruijt, B., Kutsch, W. L., Lagergren, F., Laurila, T., Law, B. E., Le Maire, G., Lindroth, A., Loustau, D., Malhi, Y., Mateus, J., Migliavacca, M., Misson, L., Montagnani, L., Moncrieff, J. B., Moors, E. J., Munger, J. W., Nikinmaa, E., Ollinger, S. V., Pita, G., Rebmann, C., Roupsard, O., Saigusa, N., Sanz, M. J., Seufert, G., Sierra, C., Smith, M.-L., Tang, J., Valentini, R., Vesala, T., and Janssens, I. A.: $\mathrm{CO}_{2}$ balance of boreal, temperate, and tropical forests derived from a global database, Global Change Biol., 13, 2509-2537, doi:10.1111/j.1365-2486.2007.01439.x, 2007.

Luyssaert, S., Schulze, E.-D., Börner, A., Knohl, A., Hessenmöller, D., Law, B. E., Ciais, P., and Grace, J.: Oldgrowth forests as global carbon sinks, Nature, 455, 213-215, doi:10.1038/nature07276, 2008.

Moyano, F. E., Kutsch, W. L., and Schulze, E.-D.: Response of mycorrhizal, rhizosphere and soil basal respiration to temperature and photosynthesis in a barley field, Soil Biol. Biochem., 39, 843-853, doi:10.1016/j.soilbio.2006.10.001, 2007.

Parker, L. W., Miller, J., Steinberger, Y., and Whitford, W. G.: Soil respiration in a Chihuahuan desert rangeland, Soil Biol. Biochem., 15, 303-309, 1983.

Pongracic, S., Kirschbaum, M. U. F., and Raison, R. J.: Comparison of soda lime and infrared gas analysis techniques for in situ measurement of forest soil respiration Can. J. For. Res., 27, 1890 1895, 1997.

Post, W. M., Emanuel, W. R., Zinke, P. J., and Stangenberger, A. G.: Soil carbon pools and world life zones, Nature, 298, 156159, 1982.

Potter, C. S. and Klooster, S.: Interannual variability in soil trace gas $\left(\mathrm{CO}_{2}, \mathrm{~N}_{2} \mathrm{O}, \mathrm{NO}\right)$ fluxes and analysis of controllers on regional to global scales, Glob. Biogeochem. Cy., 12, 621-635, 1998.

Pumpanen, J., Kolari, P., Ilvesniemi, H., Minkkinen, K., Vesala, 
T., Niinistö, S., Lohila, A., Larmola, T., Morero, M., Pihlatie, M., Janssens, I. A., Curiel Yuste, J., Grünzweig, J. M., Reth, S., Subke, J.-A., Savage, K. E., Kutsch, W. L., Østreng, G., Ziegler, W., Anthoni, P. M., Lindroth, A., and Hari, P.: Comparison of different chamber techniques for measuring soil $\mathrm{CO}_{2}$ flux, Agric. Forest Meteorol., 123, 159-176, doi:10.1016/j.agrformet.2003.12.001, 2004.

Qi, Y., Xu, M., and Wu, J.: Temperature sensitivity of soil respiration and its effects on ecosystem carbon budget: nonlinearity begets surprises Ecol. Model., 153, 131-142, 2002.

Raich, J. W. and Nadelhoffer, K. J.: Belowground carbon allocation in forest ecosystems, Ecology, 70, 1346-1354, 1989.

Raich, J. W. and Schlesinger, W. H.: The global carbon dioxide flux in soil respiration and its relationship to vegetation and climate, Tellus B, 44, 81-99, doi:10.1034/j.1600-0889.1992.t01-100001.x, 1992.

Raich, J. W. and Potter, C. S.: Global patterns of carbon dioxide emissions from soils, Glob. Biogeochem. Cy., 9, 23-36, 1995.

Raich, J. W., Potter, C. S., and Bhagawati, D.: Interannual variability in global soil respiration, 1980-94, Global Change Biol., 8, 800-812, 2002.

Raymond, E. S.: The Cathedral \& the Bazaar: Musings on Linux and Open Source by an Accidental Revolutionary, O'Reilly Media, Inc., Sebastopol, CA, 241 pp., 2001.

Rayner, P. J., Scholze, M., Knorr, W., Kaminski, T., Giering, R., and Widmann, H.: Two decades of terrestrial carbon fluxes from a carbon cycle data assimilation system (CCDAS), Glob. Biogeochem. Cy., 19, GB2026, doi:10.1029/2004GB002254, 2005.

Reichstein, M., Rey, A., Freibauer, A., Tenhunen, J. D., Valentini, R., Banza, J., Casals, P., Cheng, Y., Grünzweig, J. M., Irvine, J., Joffre, R., Law, B. E., Loustau, D., Miglietta, F., Oechel, W. C., Ourcival, J.-M., Pereira, J., Peressotti, A., Ponti, F., Qi, Y., Rambal, S., Rayment, M. B., Romanya, J., Rossi, F., Tedeschi, V., Tirone, G., Xu, M., and Yakir, D.: Modeling temporal and largescale spatial variability of soil respiration from soil water availability, temperature and vegetation productivity indices Glob. Biogeochem. Cy., 17, 1104, 1115, doi:10.1029/2003GB002035, 2003.

Reichstein, M. and Beer, C.: Soil respiration across scales: The importance of a model-data integration framework for data interpretation, J. Plant Nutr. Soil Sc., 171, 344-354, doi:10.1002/jpln.200700075, 2008.

Rochette, P., Desjardins, R. L., and Pattey, E.: Spatial and temporal variability of soil respiration in agricultural fields, Can. J. Soil Sci., 71, 189-196, 1991.

Rodeghiero, M. and Cescatti, A.: Spatial variability and optimal sampling strategy of soil respiration, Forest Ecol. Manage., 255, 106-112, doi:10.1016/j.foreco.2007.08.025, 2008.

Rosenthal, R.: The file drawer problem and tolerance for null results, Psychological Bulletin, 86, 638-641, doi:10.1037/00332909.86.3.638, 1979.

Rustad, L. E., Huntington, T. G., and Boone, R. D.: Controls on soil respiration: implications for climate change, Biogeochemistry, 48, 1-6, doi:10.1023/A:1006255431298, 2000.

Rustad, L. E., Campbell, J. L., Marion, G. M., Norby, R. J., Mitchell, M. J., Hartley, A. E., Cornelissen, J. H., Gurevitch, J., and GCTE-NEWS: A meta-analysis of the response of soil respiration, net nitrogen mineralization, and aboveground plant growth to experimental ecosystem warming, Oecologia, 126,
543-562, 2001.

Saiz, G., Green, C., Butterbach-Bahl, K., Kiese, R., Avitabile, V., and Farrell, E. P.: Seasonal and spatial variability of soil respiration in four Sitka spruce stands, Plant and Soil, 287, 161-176, doi:10.1007/s11104-006-9052-0, 2006.

Savage, K. E., Davidson, E. A., and Richardson, A. D.: A conceptual and practical approach to data quality and analysis procedures for high-frequency soil respiration measurements, Functional Ecology, 22, 1000-1007, doi:10.1111/j.13652435.2008.01414.x, 2008.

Schlesinger, W. H.: Carbon balance in terrestrial detritus, Annual Reviews in Ecology and Systematics, 8, 51-81, 1977.

Singh, J. S. and Gupta, S. R.: Plant decomposition and soil respiration in terrestrial ecosystems, The Botanical Review, 43, 449528, 1977.

Sponseller, R. A. and Fisher, S. G.: The influence of drainage networks on patterns of soil respiration in a desert catchment, Ecology, 89, 1089-1100, doi: 10.1890/06-1933.1, 2008.

Subke, J.-A., Inglima, I., and Cotrufo, M. F.: Trends and methodological impacts in soil $\mathrm{CO}_{2}$ efflux partitioning: A metaanalytical review, Global Change Biol., 12, 921-943, 2006.

Tang, J., Baldocchi, D. D., and Xu, L.: Tree photosynthesis modulates soil respiration on a diurnal time scale, Global Change Biol., 11, 1298-1304, 2005.

Tarnocai, C., Canadell, J. G., Schuur, E. A. G., Kuhry, P., Mazhitova, G., and Zimov, S. A.: Soil organic carbon pools in the northern circumpolar permafrost region, Glob. Biogeochem. Cy., 23, GB2023, doi:10.1029/2008GB003327, 2009.

Thierron, V. and Laudelout, H.: Contribution of root respiration to total $\mathrm{CO}_{2}$ efflux from the soil of a deciduous forest, Can. J. For. Res., 26, 1142-1148, doi:10.1139/cjfr-26-7-1142, 1996.

Tjoelker, M. G., Oleksyn, J., and Reich, P. B.: Modelling respiration of vegetation: evidence for a general temperature-dependent Q10, Global Change Biol., 7, 223-230, 2001.

Trumbore, S. E.: Carbon respired by terrestrial ecosystems-recent progress and challenges, Global Change Biol., 12, 141-153, doi:10.1111/j.1365-2486.2005.01067.x, 2006.

van't Hoff, J. H.: Lectures on Theoretical and Physical Chemistry. Part 1. Chemical Dynamics, Edward Arnold, London, 1898.

Vincent, G., Shahriari, A. R., Lucot, E., Badot, P.-M., and Epron, D.: Spatial and seasonal variations in soil respiration in a temperate deciduous forest with fluctuating water table, Soil Biol. Biochem., 38, 2527-2535, 2006.

Wan, S., Hui, D. and Luo, Y.: Fire effects on nitrogen pools and dynamics in terrestrial ecosystems: a meta-analysis, Ecol. Appl., 11, 1349-1365, 2001.

Wayson, C. A., Randolph, J. C., Hanson, P. J., Grimmond, C. S. B., and Schmid, H. P.: Comparison of soil respiration methods in a mid-latitude deciduous forest, Biogeochemistry, 80, 173-189, doi:10.1007/s10533-006-9016-8, 2006.

Webster, K. L., Creed, I. F., Beall, F. D., and Bourbonnière, R. A.: Sensitivity of catchment-aggregated estimates of soil carbon dioxide efflux to topography under different climatic conditions, J. Geophys. Res.-Biogeosci., 113, G03040, doi:10.1029/2008JG000707, 2008.

Wise, M., Calvin, K. V., Thomson, A. M., Clarke, L. E., BondLamberty, B., Sands, R. D., Smith, S. J., Janetos, A. C., and Edmonds, J. A.: Implications of limiting $\mathrm{CO}_{2}$ concentrations for land use and energy, Science, 324, 1183-1186, 
doi:10.1126/science.1168475, 2009.

Zhou, T., Phi, P., Hui, D., and Luo, Y.: Global pattern of temperature sensitivity of soil heterotrophic respiration $(\mathrm{Q}(10))$ and its implications for carbon-climate feedback, J. Geophys. Res.Biogeosci., 114, G02016, doi:10.1029/2008JG000850, 2009.
Zobitz, J. M., Moore, D. J. P., Sacks, W. J., Monson, R. K., Bowling, D. R., and Schimel, D. S.: Integration of processbased soil respiration models with whole-ecosystem $\mathrm{CO}_{2}$ measurements, Ecosystems, 11, 250-269, doi:10.1007/s10021-0079120-1, 2008. 